\title{
RIVERSIDE TOURISM IN AN URBAN AREA - HOW CAN IT WORK?
}

\author{
Alžbeta Királová, Iveta Hamarneh
}

\begin{abstract}
Tourism is attracted to urban areas mostly as a result of the built cultural heritage, urban amenities, lifestyle, cultural traditions, and cultural events. An increasing number of visitors often led to inconvenience for residents and can affect the value of the historic site. Prague is the most visited destination in the Czech Republic. Sustainable development and involvement of the riverside area are from this aspect one of the ways how to relieve the heavily visited World Heritage Area from visitors. Indicators as Tourist density rate, Defert's tourist function index, Index of a territorial density of tourism, Tourist penetration rate, Tourism intensity, and Tourism intensity rate were calculated to detect the current state of the intensity of visitors flow in the protected area. Literature review, content analysis of documents, interviews, Community Engaged Mapping, Asset Mapping, and Community Transect Walk been conducted to determine the destinations' attractiveness potential.
\end{abstract}

Keywords: Prague, Vltava River, sustainable development, urban tourism, riverside tourism, diversification

\section{Introduction}

Tourism has a positive impact on economic growth and employment in destinations; it helps to raise local awareness of the value of natural and cultural sites by supporting local handicrafts, cuisine, traditions or by offering alternative economic activities. Tourism is an important aspect of the life of people in destinations and a means of achieving community development (Sharpley, Tefler 2002).

On the other side, tourism can disrupt the original lifestyle of the residents and order and causes environmental deterioration, traffic congestion, and rising living costs. Attention must be paid to the relationship between heritage sites and sustainable tourism to avoid the possible negative impact of tourism on the destination Tourism requests the right balance between economic benefit and undesirable impacts. Responsible tourism can be a driver for preservation and conservation of heritage sites and a vehicle of sustainable development. However, if unplanned or not properly managed, tourism can be social, culturally and economically disruptive, and have a devastating effect on environments and local communities.

World Heritage sites attract high levels of tourism interest and activity. World Heritage listing is almost guaranteed to result in a massive increase in 
tourism interest. Tourism pressures represent one of the greatest threats to the settings of World Heritage sites (Brooks, 2005).

Destinations with World Heritage sites are also under an international obligation to maintain or restore the site's original values. The management's responsibility is to define a sustainable tourism development strategy and ensure that a part of tourism revenue remains in the community as a means of support for the local protection, conservation, and restoration.

The United Nations World Tourism Organization (UNWTO) defines sustainable tourism as "tourism that takes full account of its current and future economic, social and environmental impacts, addressing the needs of visitors, the industry, the environment and host communities" (UNEP, UNWTO 2005, pp. 11-12).

Sustainable tourism development must meet three core objectives (UNEP, UNWTO, 2005):

- develop long-term economic operations, providing socio-economic benefits for all stakeholders;

- optimal use of natural resources;

- respect the socio-cultural authenticity of host communities.

There are many types of research focusing on the impacts of tourism in the destinations. Beeton (2006) and Richards and Hall (2000) states that for many local communities are tourism a tool for stimulating changes in the social, cultural, environmental and economic area.

Destinations' residents, depending on their relationship to tourism, rather perceive tourism as a "blessing" and others see it rather as a "blight" (Smith, 2001). In most cases, tourism as a "blessing" is perceived by people who can in some way benefit from tourism. As a "blight" is tourism usually considered when it has negative impacts on the environment. Sharma (2004) states that in destinations, where residents have more positive attitudes towards tourism, tourism development will be more successful. In destinations where residents benefit from tourism development they will perceive tourism more positively and will support tourism planning and development in a community (Chon, 2000).

Tourism has the "ability" to devalue its equity business activities. It happens in connection with the absence of regulation of tourism development (concerning its random development).

World Heritage sites are a major source of tourism attraction. They were especially vulnerable to tourism congestion, which can cause serious degradation to many of the special values and characteristics of these sites. Congestion can affect the long-term economic, environmental, cultural and social sustainability of tourism. Careful management practices and productive cooperation between stakeholders are necessary to reduce or avoid tourism congestion and ensure the conservation of these sites (Brook, 2005).

Successful destinations innovate their traditional tourism products and try to offer emotions to visitors. Emotions are brought to visitors by stories and can 
motivate them to visit sites that are not so heavily visited. The post-modern visitors led destinations to a profound transformation of traditional tourism products, with a focus on emotions.

\section{Urban Tourism}

Urban tourism is a concept that emerged after 1970 and is developing especially after 1990; however, Christaller (1933) already called cities as "central places" back in 1930. He states that cities offer various services for their narrow and wide surroundings as well as goods.

"Renewed interest in urban tourism since the beginning of the 1980s has brought about a sharp upturn in this kind of tourism. The fact that people are taking more, but shorter, holidays, the advent of the single market and the general increase in mobility has also helped to build up urban tourism in Europe (EC, 2000, p. 4)."

Since the 90's several studies on urban tourism have been published (Ashworth, 1992, Jansen, Verbeke, 1986, Cazes, Portier, 1996, Van Den Berg, 1995, Page, 1995, Jud, Fainstein, 1999, Pearce, 2001, Shaw, Williams, 1994, Schnell, Landgrebe, 2005).

Ashworth (1992) noted that urban tourism is a specific part of the urban life. Judd and Fainstein (1999) identified public tourism places regardless of the cities' size as follows: (1) holiday resorts, (2) towns of historical interest, and (3) created towns.

Law (2002) characterizes urban tourism very simply as tourism in urban areas. According to the European Commission, „urban tourism is complex, difficult to pin down and define, and depends on many factors such as the size of the town, its history and heritage, its morphology and its environment, its location, its image" (EC 2000, p. 21).

It can be agreed with Gârbea (2013, p. 196) that "urban tourism represents all attractive tourist resources of a city aimed at attracting visitors and residents, in which various types of tourism are interfering and contributing to the development and regeneration of urban areas."

It is hard to identify urban areas as tourism destinations as these areas are not exclusively used by visitors only but also by residents and people working there (Page, 1995, Law, 1996, Maitland, Ritchie, 2009).

Inner-city leisure spaces, waterfront developments, festival marketplaces, casinos, museums, conference centers and sports stadia are the physical manifestations of a wave of new local economic development initiatives for urban tourism and economic regeneration (Rogerson, 2002, pp. 170-171).

Without a doubt, urban tourism can generate income and employment in the urban area. Schofield (2001) states that urban tourism can create jobs and revenues for a government that is often higher than the income from another type of destinations. 
The global options for travel destinations are extensive, so cities compete alongside all others, for visits longer than short break or single visits (Dwyer et al., 2009).

Urban areas are usually places with a dense population, a major transport hub and a gateway for further travel in the region, commercial, financial and industrial centers. They offer a variety of recreational and cultural experiences (Ashworth, Tunbridge, 1990, Page, 1995). People have always been attracted to urban areas for different reasons (e.g. visiting friends and relatives, transit, business, culture). As tourism became an important part of cities' economy, they are investing in the development of tourism offer.

Based on some authors (Ashworth, Tunbridge 1990, Jansen-Verbeke, 1986; Shaw, Williams 1994) the following motives enhance urban tourism: (1) Visiting friends and relatives; (2) Business; (3) Conference and exhibition; (4) Education; (5) Culture and heritage; (6) Religion and pilgrimage; (7) Leisure shopping. These motives can be further extended with as following: (1) Sport; (2) Food and drinks; (3) Specific topics (myths); (4) Dark tourism; (5) Cruise. The presented motives point out the comprehensiveness of the urban tourism and the complementarity of the different cities tourism offer e. g. Capital cities as Prague (Law, 1996; Page 1995).

Smith, Macleod and Hart Robertson (2010) state that urban tourism is one of the most complex forms of tourism to manage.

Cities "cater to seniors, who undertake more sightseeing and are more likely to appreciate cultural and historic heritage; young people, who are attracted by the excitement of the urban environment along with entertainment, nightlife and sporting events; business travelers; and the meetings, incentives, conventions and exhibition market (Edwards, Griffin, Hayllar, 2008, p. 1033)."

Warren and Taylor (2003) describe cities' attractivity as dining out and shopping facilities, performances, events and nightlife together with wide range of accommodation capacities (often in a different design or thematic ones).

Thinking about visitors' satisfaction cities cannot ignore the local community, the city-region residents and the people working within the city (Page, Hall 2002) as they also use the infrastructure and share these services and spaces with tourists (Pearce, 2001). The urban tourism development should, therefore, seek a more productive and harmonious relationship among visitors, host communities and the environment (Savage, Huang, Chang, 2004).

Page (1995) stated that many European cities improved their centers by creating pedestrian zones, establishing parks and cycling routes, by investing in modern shopping centers and developing the city's marketing around a specific theme. Jansen-Verbeke (1986) includes that it is also necessary to improve the cities accessibility, create parking facilities and supporting tourism infrastructure (e. g. tourist information offices, signposts, and guides).

Tourism is "one of many economic activities within a city, and it must 
compete with some other industries for resources such as labor and land. Also, within urban areas, there is a complex mix of constraints on development, with natural environmental factors being less significant and cultural heritage and residential factors greater than in other forms of tourism (Edwards, Griffin, Hayllar, 2008:1033)."

As Warren and Taylor (2003) point out, there is a correlation between the ability of the city to meet the needs of its citizens and its ability to attract visitors. If residents are not attracted to their city, why should be the visitors (Warren, Taylor, 2003)?

Based on his studies on the relationship between tourism and urban areas Law (2002) defined three elements of city resources. Primary elements consist of facilities for activities such as cultural sport and leisure facilities, and factors of recreation and relaxation such as physical characteristics and socio-cultural characteristics. Primary facilities are the main reasons for visiting the city. Secondary elements are related to accommodation services, restaurants, shops, and other services. The additional items are designed to facilitate access to primary and secondary elements through accessibility e. g. Parking places, tourist information offices, leaflets, and maps.

A wide variety of existing tourism resources in the urban area is a precondition of a city to attract tourists with various goals and motivations. Tourists are seeking diversity in a broad land of opportunities likely to be merged during the stay of a few days. If the city offers a greater variety of attractions and complementary capabilities, it can become more competitive in the tourism market.

\section{Riverside Tourism}

Rivers have been a central place in human history since ancient times. Rivers helped to foster the wealth of human settlements focused on agriculture and trade. Modern cities are associated with rivers that become a significant tourism resource. They can be used for transportation but also for leisure, sport, and cultural activities. Rivers can work as an attractive backdrop to the business or art activities of the city.

Urban waterfronts have always attracted people because they pose a variety of opportunities for tourism, economic, and community development. Rivers creates aesthetic and entertainment value while at the same time generating income for the city.

The mix of tourists and residents in the urban area creates mixed-use spaces as the urban waterfront.

According to Jansen-Verbeke (1986), waterfronts are part of the urban tourism product and can play a major role in attracting visitors to a city. They can also be a place of residence, work or recreation for residents. Based on their research, Breen and Rigby (1996) distinguish six types of waterfronts: (1) 
commercial waterfronts, (2) cultural, (3) educational and environmental waterfronts, (4) historical waterfronts, (5) recreational waterfronts, (6) private waterfronts and working waterfronts.

Griffin et al. (2008) state that having a waterfront location make cities interesting for tourists. Jansen-Verbeke and Lievois (1999) add that using waterfronts in tourism requires from cities developing parking places, open-space facilities, sports areas, ensuring water quality and accessibility of these areas. Destination managements should at the same time keep in mind that waterfronts are natural resources and sources for biodiversity.

Cities around the world realized that waterfronts open a new possibility for attracting tourists and therefore they are redeveloping and conserving their waterfronts, creating new leisure, recreational, and tourism spaces (Craig-Smith, 1995, Dodson, Killian, 1998, Law, 1996). Warren and Taylor (2003) point out the importance of historic structures within waterfront areas for tourism. Waitt and McGuirk (1997) highlight the significance of cultural tourism as a means for revitalizing waterfront areas.

Some authors (Griffin, Hayllar, 2006, Krolikowski, Brown, 2008) add that tourists visit waterfronts often not for specific attractions but the feel and ambiance of these areas hence for their "genius loci."

Besides providing spectacular settings and recreational and leisure opportunities, rivers are also sources of water for human consumption. It must be stated that rivers are sensitive to human activities and interventions, so the sustainable development of riverside areas are crucial.

\section{Methodology}

The analysis and data presented in this paper are based on primary and secondary research. For detection of the current state of the intensity of visitors flow in the city center, indicators as Tourist density, Defert's tourist function index, Number of beds $/ \mathrm{km}^{2}$, Tourist penetration rate, Tourism intensity, and Tourist intensity rate were calculated. Determinating the riverside tourism potential, literature review, content analysis of documents, interviews, Community Engaged Mapping, Asset Mapping (Dorfman, 1998, Moore, 2011), and Community Transect Walk (Carter, 2005, WB, 2005) were conducted. For Asset Mapping the 2GIS application, a detailed and current information system Prague with a city map, was used.

Qualitative research, using an inductive method, was also applied to this study as it is suitable for use with a small sample. The pilot phase of the research included face-to-face interviews in a one-to-one setting with thirty residents. The specific selection criteria for the purposeful sampling as residency in Prague longer than one year and involvement in the tourism industry were determinate. The entire sample was selected by snowball sampling method. 
The research question was defined as follows: is Prague's protected area heavily impacted by tourism and if yes, is the Vltava Riverside prepared to divert the part of the visitors' flow from the protected area?

\section{Results and Discussion}

According to the research of the agency Czech Tourism (2016), Prague as a tourist destination is a stronger brand than the brand of the Czech Republic and has a stronger image than the country's total.

A.T. Kearny's 2015 in-depth analysis of global cities ranks Prague as a leader city by metric in GINI index. The report examines the top performing cities today and those with the greatest potential for the future (Mendoza et al., 2015).

For the performance of the state administration, Prague is divided into 22 administrative districts, and 57 autonomous municipal districts with elected bodies. These districts are significantly different. There are districts with the distinct character of the city center, districts with predominantly residential character, districts with the popular industrial character, housing estate districts, and districts with rural character. Many of these districts are originated by plugging the surrounding villages to the city. They differ in the degree of urbanization, population density, quality of technical infrastructure and socio-economic living conditions.

In 2015, six million six hundred five thousand and seven hundred seventysix visitors arrived in Prague; by 8.2 percent more than a year ago. While the number of visitors was continuously increasing, the average length of stay is continuously decreasing; in 2011 the average duration of stay was 2.7 nights, in 2015 it dropped to 2.5 nights.

Prague's historical center belongs since 1992 to the UNESCO World Heritage Sites.

There are 1330 protected objects in this area (including 28 national cultural monuments), 1322 protected buildings, a large number of small architectural objects, technical monuments and historic gardens and parks.

The most visited monument in 2015 was the Prague Castle (7 421000 visitors), followed by Zoological Garden (1 318382 visitors), the Old Town Hall (716 440 visitors) and the Jewish Museum (629 126 visitors). Table 1 shows the defined elements of urban tourism in Prague Riverside Area.

For detection of the current state of the intensity of visitors flow in the city center, different tourism indicators were calculated. Table 2 shows the value of indicators for Prague and the protected area. 
Table 1: Elements of urban tourism in Prague Riverside Area

\begin{tabular}{|c|c|}
\hline \multicolumn{2}{|c|}{ Primary elements } \\
\hline Facilities for activities & Factors of leisure and relaxation \\
\hline $\begin{array}{l}\text { Museums: The Water Museum, Výtoň } \\
\text { Museum, Charles Bridge Museum, Czech } \\
\text { Granat Museum, Kepler Museum, Museum } \\
\text { of Czech Music, Franz Kafka Museum, Art- } \\
\text { Industry Museum and the Jewish Museum; } \\
\text { Galleries: Mánes and Sovovy Mlýny } \\
\text { Theatres: National Theatre, Braník Theatre, } \\
\text { Theatre na Zábradlí; } \\
\text { Concert halls: Rudolfinum; } \\
\text { Planetarium; } \\
\text { Castles, chateaus and Palaces: Vyšehrad, } \\
\text { Trója and Zbraslav Chateau, Žofín and } \\
\text { Lichtenstein; }\end{array}$ & \multirow{3}{*}{$\begin{array}{l}\text { Physical characteristics: Česká Vysočina's } \\
\text { sub province Poberounská soustava. Due to } \\
\text { mild climate there are a lot vineyards in the } \\
\text { city (e. g. Grébovka, Vinohrady); } \\
\text { Climate: temperate climate with lowest } \\
\text { average temperature in January }-0.9^{\circ} \mathrm{C} \text {, and } \\
\text { the highest average temperature in June - } \\
19^{\circ} \mathrm{C} \text {; } \\
\text { Hydrology: } 3 \text { rivers Vltava, Berounka and } \\
\text { Rokytka and } 99 \text { minor waterways (creeks) } \\
\text { Botič, Śárka, Dalejský, Kunratice and Motol } \\
\text { with a total length of } 337.8 \text { km, } 98 \\
\text { waterworks; } \\
\text { Fauna: the largest fauna area is the ZOO, } 19 \\
\text { species of fish in the rivers, swans and ducks; } \\
\text { Flora: woods cover } 10 \% \text { of the area of the } \\
\text { city, parks cover } 5 \% \text { of its area; } \\
\text { Emergency Service Company: the oldest } \\
\text { company of its type in Europe; } \\
18 \text { bases located throughout the city } \\
\text { including one on the riverside }\end{array}$} \\
\hline $\begin{array}{l}\text { Sports facilities: Yacht and canoeing clubs } \\
\text { (4), water canals (2), swimming polls (3), } \\
\text { rowing clubs (2), tennis clubs (3), volleyball } \\
\text { clubs (1), football clubs (1) or golf clubs (1). } \\
\text { Religious Monuments: Vyšehrad, Sv. } \\
\text { Klimenta, Michaela Archanděla, Sv. Filipa a } \\
\text { Jakuba, Anežský klášter, Emauzy; }\end{array}$ & \\
\hline $\begin{array}{l}\text { Exhibitions: } 9 \text { tourism exhibitions; } \\
\text { Congresses: } 41 \text { Congresses and Conferences } \\
\text { Facilities with more than } 200 \text { meeting rooms; } \\
\text { Festivals: music and food festivals } \\
\text { Sport Events: Stvanice with tennis facilities, } \\
\text { marathon and half-marathon in Prague; in } \\
2016 \text { is Prague The European Capital of } \\
\text { Sport }\end{array}$ & \\
\hline \multicolumn{2}{|l|}{ Secondary elements } \\
\hline \multicolumn{2}{|l|}{$\begin{array}{l}\text { Accommodation: } 495^{*} \text { hotels, } 2434^{*} \text { hotels, } \\
2323^{*} \text { hotels and } 92 * \text { hotels, } 66 \text { hostels and } \\
78 \text { pensions, } 6 \text { botels; } \\
\text { Restaurants: } 261 \text { restaurants, } 131 \text { beerhouses, } \\
64 \text { wine bars, } 106 \text { cafés and } 99 \text { bars; } \\
\text { Shopping centers: Nový Smíchov, Quadrio, } \\
\text { MY, Kotva and Palladium. }\end{array}$} \\
\hline \multicolumn{2}{|l|}{ Additional elements } \\
\hline \multicolumn{2}{|c|}{$\begin{array}{l}\text { Travel agencies: } 622 \text { travel agencies tour operators; } 5 \text { tourism information agencies; } \\
\text { Tourist Transport: Prague Steamboat Company, Prague Boats, historical boat Venezia, pedal } \\
\text { boats, historical cars; } \\
\text { Public transport: on the riverside are metro stations Nádraží Holešovice, Vltavská, Florenc (C), } \\
\text { Palmovka, Invalidovna, Křižíkova, Florenc, Náměstí Republiky, Národní trída, Karlovo } \\
\text { náměstí, Anděl, Smíchovské nádraží (B), Staroměstská, Malostranská (A), and trams number } \\
1,2,3,4,5,6,8,9,10,12,14,15,16,17,18,20,21,22,25,26\end{array}$} \\
\hline
\end{tabular}

Source: Authors based on Law, 2002, p. 43 
Table 2: Indicators

\begin{tabular}{|c|c|c|}
\hline Indicator & Prague City & $\begin{array}{l}\text { Prague World } \\
\text { Heritage Site }\end{array}$ \\
\hline Size of the area & $496 \mathrm{~km}^{2}$ & $8.66 \mathrm{~km}^{2}$ \\
\hline Number of inhabitants & 1.247 million & 52000 \\
\hline Population density & $2534 / \mathrm{km}^{2}$ & $7500 / \mathrm{km}^{2}$ \\
\hline $\begin{array}{l}\text { Tourist Density Ratio = average } \\
\text { length of stay x no. of tourists /( } 365 \\
x \text { area }\left(\text { in } \mathrm{km}^{2}\right)(\text { Smith, Krannich, } \\
1998)\end{array}$ & $87.57 / \mathrm{km}^{2}$ & $5015.61 / \mathrm{km}^{2}$ \\
\hline $\begin{array}{l}\text { Defert's tourist function index } \\
\text { measures the impact of tourist } \\
\text { supply on socio-economic substrate } \\
\text { of the territory being studied the } \\
\text { higher the index is, the more the } \\
\text { tourist-receptive field is present in } \\
\text { the local economy }\end{array}$ & 7.24 & $\begin{array}{r}67.29 \\
\text { Predominantly tourism } \\
\text { area }\end{array}$ \\
\hline $\begin{array}{l}\text { Index of territorial density of } \\
\text { tourism - number of beds } / \mathrm{km}^{2}\end{array}$ & 183.57 & 4040.88 \\
\hline $\begin{array}{l}\text { Tourist penetration rate tourist } \\
\text { penetration rate = average length of } \\
\text { stay x no. of tourists/(population x } \\
365) \times 1000 \text { (Smith, Krannich, } \\
1998)\end{array}$ & 34.83 & 835.29 \\
\hline $\begin{array}{l}\text { Tourism intensity }=\text { number of } \\
\text { overnight stay/number of population }\end{array}$ & 12.66 & 113.47 \\
\hline $\begin{array}{l}\text { Tourist intensity rate = number of } \\
\text { tourists/population x } 100 \text { (Smith, } \\
\text { Krannich, 1998) }\end{array}$ & 525 & 12703.41 \\
\hline
\end{tabular}

Source: Authors' processing based on data from Prague City Tourism (PCT, 2016)

The indicators in Table 2 show that the city center is heavily impacted by tourism. To keep Prague tourism sustainable the tourism offer must be diversified. Prague tries to help to the busy historical heart of the city but without success visitors must have had a reason to leave the center. The river is the blue corridor of the city that can increase the quality of life not only for the residents but also that of the tourists.

One of the possibilities where the tourist flow can be redirected is the Vltava River riverside. Vltava is the longest river in the Czech Republic (433 km); its length in Prague is about $31 \mathrm{~km}$. 
For Czechs the Vltava is much more than just a "river" - it has a national and symbolic significance. Prague and the whole history of the city and the entire nation are closely connected with the Vltava River. This important position of the river can be utilized redirecting the domestic tourist's flow.

The Riverside is a place for sport, free and leisure time activities, water sports, wellness, and cultural activities but it is currently used in tourism only partially.

The results of the Community Engaged Mapping, Asset Mapping, and Community Transect Walk, as well as the results of the interviews, shows that the Vltava Riverside already disposes of assets that support further development of tourism and leisure activities. These assets include unique tangible and intangible natural, cultural and technical heritage, sports facilities and events including outdoor activities. These assets should be utilized and incorporated into the Prague's tourism product and promoted in the tourism market.

There are ten islands in the river; the Slovanský Island and the Střelecký Islands are the biggest ones. In 1865, regular steam navigation started on the Vltava River. The river flows through the most valuable historical part of the city (one $\mathrm{km}$ long), and visitors can take advantage of nine places, where they can board a shorter or longer cruise.

The review of the asset base suggests that Prague Riverside has some real strength as well as some gaps, and the city faces some challenges and opportunities. The key points can be summarized in the form of a SWOT analysis. The Importance shows how important strength or a weakness is at the Riverside. A score given to each factor indicate whether it is a major (3) or minor (1) strength for the Riverside. The Score is a result of importance multiplied by rating. It allows prioritizing the strengths and weaknesses. The Riverside should rely on its most significant strengths and try to convert or defend its weakest parts.

The strengths with the highest score were identified as Amazing views (0.63); Public transport (0.39); Clean water (0.26); UNESCO heritage (0.24); Diversity of the riverside area (0.21); Stable water level (0.21).

Weaknesses with the highest score were defined as Lack of supporting services (0.9); Heavy traffic (0.38); Uneven use of the area for tourism (0.21); Aging infrastructure (0.2); the Inappropriate structure of hospitality services (0.2).

The Importance of opportunities and threats shows to what extent the external factor might impact the tourism development in the Riverside area. The Probability of occurrence is showing how likely the opportunity or threat will have any impact on tourism development in the Riverside area. Importance multiplied by Probability gives a Score by which the Riverside will be able to prioritize opportunities and threats. Attention must be paid to the factors having the highest score, and the factors that will not likely affect tourism development in the Riverside area should be ignored.

The opportunities with the highest score were identified as Public sports culture development (0.45); Involvement of Prague municipalities (0.4); 
Improvement of the quality of services (0.4); Cooperation of entrepreneurs in tourism (0.3); Introduction of new sports (0.3).

The threats with the highest score were defined as Lack of development plan (0.6); Lack of cooperation between Prague municipalities (0.3); Weak tourism management (0.24); No sustainable tourism development (0.24).

Based on the analysis provided it can be stated the Vltava Riverside is rich in unique tangible and intangible natural, cultural and technical heritage. The Riverside is also a place for sport, free and leisure time activities, water sports, wellness, cultural events and sports.

Conditions for "getting wet" adventure tourism are developed in the area of the Vltava Riverside - activities as surfing, canoeing, kitesurfing, wakeboarding, rafting on white water, water skiing, diving, windsurfing, and fishing can be provided there.

The ability to insert stories into everything that visitors can perceive and use is natural. As Bateson (1972) notes, people think and talk in stories. Writing and travel are closely connected (Hulme, Youngs, 2002). The travelers' tales had a long history and played a major role in enhancing imagination of people and motivating them to travel (e. g. Marco Polo and John Mandeville in the Middle Ages, later Thomas More).

There are several books published on the Vltava River, people and monuments are connected to it, documentary films were made, music was composed, and stories are told of the generations of water sports lovers and residents on the riverside. The most of these stories are based on reality, but some of them are mystification. In tourism are both important as they can attract tourists to the destination; sometimes the mysteries, as they enhance emotions and imaginations, are even more attractive to tourists.

Stories about the Waterman, who is the embodiment of the spirit of water, can be found almost everywhere where there is water, whether it is a lake, pond, river or stream and the Vltava Riverside is not an exception. These stories can be used for development of a tourism product.

Scenes from Amadeus, Mission Impossible, XXX, Shanghai Knights, Casino Royale, The Bourne Identity Van Helsing, Blade II, Hannibal Rising, The League of Extraordinary Gentlemen, and 50 music videos were shot on the Vltava Riverside. Places, where these scenes were shot, can also be used in tourism packages.

The team of young people who want to change the public opinion of the homeless and make it easier for people without homes to return to ordinary social life created a web page www.pragulic.cz. Pragulic is a concept of the unique homeless experience with the aim to create agents of change, who, based on an intensely personal experience, know what homelessness means, who lost all the myths and prejudices and used this experience and act on it in their further lives. These "guides" can offer a visitors a different view of the city its Riverside. 


\section{Conclusion}

Based on the results of the analysis provided, it can be stated that Prague World Heritage area is heavily visited by tourists and the tourist flow can have the significant impact not only on heritage site itself but also on the quality of life of residents and tourists.

The assets mapping results indicate that the Vltava Riverside area is rich intangible, and intangible assets that could be utilized in tourism and tourism plays a major role in the future development of Vltava Riverside. Amazing views, high level of public transport and cleanliness of the water are the most important strengths of the Riverside. On the other hand, lack of supporting services, heavy traffic and uneven use of the area for tourism are the weaknesses with the highest importance. The biggest opportunity for the Riverside tourism development can be seen in public sports culture development, the involvement of Prague municipalities and improvement of the quality of services. Attention must be paid to the creation of development plan, cooperation between Prague municipalities, improvement of tourism management and sustainable tourism development.

Involving tourism entrepreneurs, residents and Prague municipalities in the development of Prague Riverside Tourism is in this case crucial as it can help to increase the acceptance of the development process and investments regarding this area. Redirection of part of the tourist flow to the riverside area cannot be successful without the collaboration of all stakeholders.

Considering saying the opportunities for future research is in expanding the number of interviewees and widens the interviews to the visitors. There is also a possibility to calculate the indicators for time series data.

\section{Acknowledgement}

This paper is based on research project "Diversification of Prague Tourism Offer with Focus on the Vltava Riverside - The Primary and Secondary Offer Analysis", GA/2016/6-101.

\section{References}

ASHWORTH, G. J. 1992. Is There an Urban Tourism? In Tourism Recreation Research. ISSN 2320-0308, 1992, vol. 17, no. 2, pp. 2-8.

ASHWORTH, G. J. - TUNBRIDGE, J. E. 1990. The Tourist-historic City. London: Belhaven.

BATESON, G. 1972. Steps to Ecology of Mind: Collected Essays in Anthropology, Psychiatry, Evolution, and Epistemology. San Francisco: Chandler Publishing Company. 
BEETON, S. 2006. Community Development through Tourism. Australia: Landlink Press.

BREEN, A. - RIGBY, D. 1996. The New Waterfront: A Worldwide Urban Success Story. London: Thames and Hudson.

BROOKS, G. 2005. Guidebook for Tourism Congestion Management at Natural and Cultural Heritage Sites, a New Publication by the World Tourism Organization. In 15th ICOMOS General Assembly and International Symposium: Monuments and Sites in their Setting - Conserving Cultural Heritage in Changing Townscapes and Landscapes', 17 - 21 October 2005, Xi'an, China.

CARTER, J. ed. 2005. Participatory Monitoring and Evaluation. Field Experiences, NGO Programme Karnataka-Tamil Nadu. Hyderabad: Intercooperation.

CAZES, G. - POTIER, F. 1996. Le Tourism et la Ville: Experiences Européenes. Paris: L'Harmattan.

CHON, K. S. 2000. Tourism in Southeast Asia: a New Direction. New York: Haworth Hospitality Press.

CHRISTALLER, W. 1933. Die Zentralen Orten in Süddeutschland. Jena: Gustav Fischer.

CRAIG-SMITH, S. J. 1995. The Role of Tourism in Inner-harbor Redevelopment: A Multinational Perspective. In S. J. Craig-Smith \& M. Fagence (Eds.), Recreation and Tourism as a Catalyst for Urban Waterfront Redevelopment: An International Survey (pp. 16-35). Westport, Conneticut: Praeger.

DODSON, B. - KILLIAN, D. 1998. From Port to Playground: The Redevelopment of the Victoria and Alfred Waterfront, Capetown. In D. Tyler, Y. Guerrier, \& M. Robertson (eds.), Managing Tourism in Cities: Policy, Process, and Practice, pp. 139-162. Chichester, England: John Wiley.

DORFMAN, D. 1998. Mapping Community Assets Workbook, Portland: Northwest Regional Educational Laboratory.

DOXEY, A. 1975. Causation Theory of Visitor-Residents Irritants; Methodology and Research Inference. In Sixth Annual Conference Proceedings of the Travel Research Association San Diego, pp. 195-198.

DWYER, L. - EDWARDS, D. - MISTILIS, N. - ROMAN, C. - SCOTT, N. 2009. Destination and Enterprise Management for a Tourism Future. In Tourism Management. ISSN 02615177, 2009, vol. 30, no. 1, pp. 63-74,.

EC 2000. Towards Quality Urban Tourism: Integrated Quality Management (IQM) of Urban Tourist Destinations. Brussels: European Comission.

EDWARDS, D. - GRIFFIN, T. - HAYLLAR, B. 2008. Urban Tourism Research: Developing an Agenda. In Annals of Tourism Research. ISSN 0160-738, 2008, vol. 35, no. 4, pp. 1032-1052.

GÂRBEA, R. V. 2013. Urban Tourism Between Content and Aspiration for Urban Development. In Management \& Marketing. ISSN 0019-8501, 2013, vol. 9, no. 1, pp. 193-201. 
GRIFFIN, T. - HAYLLAR, B. 2006. Historic Waterfronts as Tourism Precincts: An Experiential Perspective. In Tourism and Hospitality Research. ISSN 10991603, 2006, vol. 7, no. 1, pp. 3-16.

GRIFFIN, T. - HAYLLAR, B. - EDWARDS, D. 2008. Places and People: A Precinct Typology. In B. Hayllar, T. Griffin, \& D. Edwards (eds.), City Spaces - Tourist Places: Urban Tourism Precincts (pp. 39-61). Oxford, UK: Butterworth-Heinemann.

HULME, P. - YOUNGS, T. 2002. Introduction. In P. Hulme and T. Youngs (eds.) The Cambridge to Travel Writtings, pp. 1-16. Cambridge: Cambridge University Press.

JANSEN-VERBEKE, M. 1986. Inner-city Tourism: Resources, Tourists and Promoters. In Annals of Tourism Research. ISSN 0160-7383, 1986, vol. 13, no. 1, pp. 79-100.

JANSEN-VERBEKE, M. - LIEVOIS, E. 1999. Analysing Heritage Resources for Urban Tourism in European Cities. In R. Butler \& D. Pearce (Eds.), Contemporary Issues in Tourism Development, pp. 81-107. New York: Routledge.

JUDD, D. R. - FAINSTEIN, S. S. eds. 1999. The Tourist City. New Haven: Yale University Press.

KROLIKOWSKI, C. - BROWN, G. 2008. The Structure and Form of Urban Tourism Precincts: Setting the Stage for Tourist Performances. In B. Hayllar, T. Griffin, \& D. Edwards (eds.), City Spaces - Tourist Places: Urban Tourism Precincts, pp. 127-149. Oxford: Butterworth-Heinemann.

LAW, C. ed.. 1996. Tourism in Major Cities. London: International Thomson Business Press.

LAW, C. 2002. Urban Tourism: The Visitor Economy and the Growth of Large Cities. London: Continuum.

LAWS, E. 1995. Tourist Destination Management. London: Routledge.

MAITLAND, R. - RITCHIE, B. 2009. City Tourism: National Capital Perspectives. Australia: University of Queensland.

MENDOZA, A. P. - GOTT, J. - PETERSON, E. R. - HALES, M. 2015. Global Cities 2015: The Race Accelerates. Atlanta: ATKearny.

MOORE, S. 2012. Cultural Mapping: Building and Fostering Strong Communities. In D. Borwick (ed.) Building Communities, Not Audiences: The Future of the Arts in the United States. Winston-Salem: ArtsEngaged.

NPÚ 2010. Prague Heritage Site, [online, quoted to 22.06.2016]. Available at: http://www.archeopraha.cz/mapa-vyznamnych-archeologickych-ploch-vprazske-pamatkove-rezervaci.

PAGE, S. 1995. Urban Tourism. London: Routledge.

PAGE, S. - HALL, M. 2002. Managing Urban Tourism. Harlow, England: Prentice Hall.

PEARCE, D. 2001. Integrative Framework for Urban Tourism Research. In Annals 
of Tourism Research. ISSN 0160-7383, 2001, vol. 28, no. 4, pp. 926-946. PTC 2015. Hosté a přenocování. Prague: Prague City Tourism. RICHARDS, G. - HALL, D. 2000. Tourism and Sustainable Community Development. London \& New York: Routledge.

ROGERSON, C. M. 2002. Urban Tourism in the Developing World: The Case of Johannesburg. In Development Southern Africa. ISSN 0376-835X, 2002, vol. 19, no. 1, pp. 169-190.

SAVAGE, V. R. - HUANG, S. - CHANG, T. C. 2004. The Singapore River Thematic Zone: Sustainable Tourism in an Urban Context. In The Geographical Journal. ISSN 1475-4959, 2004, vol. 170, no. 3, pp. 212-225.

SCHNELL, P. - LANDGREBE, S. eds. 2005. Städtetourismus. München, Wien: Oldenburg Verlag.

SCHOFIELD, P. 2001. Urban Tourism and Small Businesses. In N. Douglas, N. Douglas, \& R. Derret (eds.), Special Interest Tourism: Context and Cases, pp. 432-450. Brisbane: John Wiley and Sons.

SHARMA, K. 2004. Tourism and Socio-cultural Development. New Delhi: Sarup and Sons.

SHARPLEY, R., - TEFLER, D. J. 2002. Tourism and Development. London \& New York: Routledge.

SHAW, G., - WILLIAMS, A. M. 1994. Critical Issues in Tourism: a Geographical Perspective. Oxford: Blackwell.

SMITH, M. D. - KRANNICH, R. S. 1998. Tourism Dependence and Resident Attitudes. In Annals of Tourism Research. ISSN 0160-7383, 1998, vol. 25, no. 4, pp.783-802.

SMITH, V. L. 2001. Tourism Change and Impacts. In Smith, V. L. \& Brent, M. (eds.). Hosts and Guests Revisited: Tourism Issues of the 21st Century, pp. 107121. New York: Cognizan Communication Corporation.

SMITH, M. - MACLEOD, N. - ROBERTSON M. H. 2010. Key Concepts in Tourist Studies. London: Sage Publications.

UNEP. 2004. Environmental Impacts on Tourism. [online, quoted to 22.06.2016]. Available at: http://www.unep.fr/scp/tourism/sustain/impacts/environmental/.

UNEP - UNWTO 2005. Making Tourism More Sustainable. A Guide for Policy Makers. United Nations Environment Programme \& World Tourism Organization. Madrid: WTO

VAN DEN BERG, L. - VAN DER BORG J. - VAN DER MEER eds. 1995. Urban Tourism: Performance and Strategies in Eight European Cities. Aldershot: Avebury.

WAITT, G. - MCGUIRK, P. M. 1997. Selling Waterfront Heritage: A Critique of Millers Point, Sydney. In Tijdschrift voor economische en sociale geografie. vol. 88 , no. 4 , pp. 342-352.

WARREN, J. A. N. - TAYLOR, C. N. 2003. Developing Urban Tourism in New Zealand. Wellington: Centre for Research, Evaluation and Social Assessment. 
WB. 2005. Methodology for Transect Walk. Washington, DC: World Bank.

WTO - UNEP. 2005. Making Tourism More Sustainable, A Guide for Policy Makers, Paris, Madrid: WTO, UNEP.

Doc. Ing. Alžbeta Királ'ová, Ph.D.

Ing. Iveta Hamarneh, Ph.D.

Vysoká škola obchodní v Praze, o. p. s.

Spálená 14, 11000 Praha 1 - Nové Mesto

E-mail: kiralova@vso-praha.eu, hamarneh@vso-praha.eu 